\title{
Employee Training on Emergency Management in the New Generation Retail Outlets of Kerala
}

\author{
R. Roshan, D. Kinslin
}

\begin{abstract}
The aim of this study is to analyze the readiness of the employees of new generation retail outlets of Kerala to handle an unexpected emergency situation. The state of Kerala, a little, long stripped land in the southern tip of India has the largest

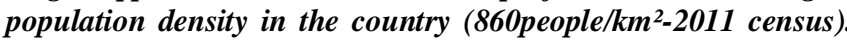
It is more vulnerable to population disasters because of its high density population and high standard of living. Records show that in the last 80 years, there has been a change in its population profile, a shift from the basic agrarian society to an urbanized consumerist society. The result is an increase in the total number of shops from 2, 31,046 in 2004 to 2, 87, 598 in 2015, with more organized and professionalized management. About 50 malls have come up in the State in the last three years and all these developments in a state were about $14.5 \%$ of the area is prone to floods and $14.4 \%$ of the area to landslides. This is one of the reason why Kerala has to be more conscious about its safety measures. And making this data even worse, the recent floods (2018) that affected the state has proved more fatal than before as all the fourteen districts were affected. The data presented in this study was collected six months prior to this recent emergency situation and was mainly focused on knowing the precautions existing in outlets with respect to employee training, to handle the most common disasters that may happen. Data was collected using an interview schedule. The analysis shows varying results as the knowledge and preparations of the staff of the outlets in most of the places is not enough to make them confident about their emergency management competence.
\end{abstract}

Keywords--- Emergency Management, New Generation Retail Outlets, Disaster Management.

\section{INTRODUCTION}

An 'emergency' can be explained as a situation of 'high caution' which usually come up after a disaster - an unforeseen, unpleasant circumstance. No corner of planet Earth is immune to this. And so, for this matter, the narrow long stripped state of Kerala is no exception. The state, known to be having the highest population density in the country (860people/ $/ \mathrm{km}^{2}-2011$ census), with narrow roads and with a high standard of living as compared to the rest of the country, is more vulnerable to population disasters

Over many times in the last century, Kerala has been experiencing a rapid socio-economic transformation, a shift of its population from the basic agrarian society to a highly advanced consumerist society. According to the statistical reports published by the Government of Kerala in 2015, the total number of shops in the state has increased over the 10 years from 231046 in 2004 to 287598 in 2015 . Of these, 120729 outlets has employees other that its owner. With a long strip of coastal line of $580 \mathrm{~km}$ on one side and the Western Ghats on the other, a width of just 35 to $120 \mathrm{~km}$ and with the highest population density: the state shows a high socio-economic vulnerability, towards the effect of disasters to its community.

According to a publication by the Kerala State Productivity Council there has been an exponential growth in the commercial buildings in the State in the last 10 years and unlike the industrial sector, commercial sector lack trained technical manpower who can manage energy systems efficiently.

UNISDR (2005) says that disaster risk reduction (DRR) is a systematic method for understanding, determining, estimating and mitigating the disaster related hazards. Its aims at decreasing the socio-economic exposure to disaster and to manage and reduce the risks connected with the environment which create them.

The World Health Organization (WHO, 2002) says that there are two stages of disaster reduction and preparedness and both stages take place alongside improvement measures that are undertaken in expecting a disaster.

Disaster mitigation is a series of efforts taken for the purpose of reducing the loss by reducing the impact of disasters. It is mostly concerned with educating and preparing the people along with providing the possible precautionary measures.

\section{BACKGROUND OF THE STUDY}

- The hazard history of the state published by the State Emergency Management Authority says that $14.5 \%$ of the State is flood prone, $14.4 \%$ is land slide prone, $55.5 \%$ of the coastal line is prone to coastal hazards and close to 70 people die of lightning every year. But the year 2018 has produced more casualties than ever predicted.

- At least two incidents of fire accidents either in buildings or in market places are reported every year.

- With the change in the profile of the population and the rise in the number of retail outlets the crowed has moved away from festival grounds and cinema halls to retail outlets.

- Reports of minor retail accidents have started coming over the last few years and safety measures required in an enclosed air-conditioned environment is often overlooked. 


\section{Objective}

Being a multi hazard prone state this research aims to study and analyze the precautions taken by a retail outlet with respect to employee training in handling an emergency situation.

\section{Methodology}

The research paper is based on the study conducted inthreedistricts of Kerala namely Kollam, Thrissur and Kannur.

It covered areas including the different types of retail outlets, the total number of employees, the number of professionals and the number of non-professionals working in these outlets and how much they are trained to handle possible emergency situations that may arise. The study should be helpful for the retailers as it tries to bring out the relevance of employee training in safe shopping. Both secondary and primary data were used for the study. The major sources of secondary data included the internet, newspaper and publications by the State Emergency Management Authority.

Primary data was collected from the retail outlets using the survey method .Interview schedule was the tool used for this purpose.

A sample study was conducted in ten retail outlets in Trivandrum. Thoseoutlets which are comparatively new, enclosed and air-conditioned were preferred for this purpose. The study was focused on the type of retail outlets, the profile of the employees working in it and the fact whether they are introduced to any of the emergency management practices.

The hypothesis formulated was strictly based on the assumption that the people working in the outlets are neither aware nor are they prepared to face an unexpected emergency while at work. In order to collect data based on this the following information was necessary.

\section{Data Description}

1. The generic category of the retail outlet,

2. The total number of employees working in each,

3. The employee profile as to whether they are professionals or non-professionals.

4. Whether they have received any training regarding emergency preparedness, emergency mitigation or emergency management.

\section{DESCRIPTIVE ANALYSIS OF THE SAMPLE RETAIL OUTLETS}

Table No.1 shows various socio-demographic profile of the retail outlets and the percentage analysis based on the sample collected.

According to Table No. 1 it can be seen that 18 retailers were from the three corporation areas (Kollam, Thrissur and Kannur).

This accounts for $37.5 \%$ of the total retail outlets.

Again, the same number of retailers have been interviewed from the 6 municipalities which formed part of the sampling regions. $25 \%$ of the respondents were from the 6 panchayats.
Table 1: Profile of the Retail Outlets

\begin{tabular}{|c|c|c|c|c|c|c|}
\hline \multirow[b]{2}{*}{$\begin{array}{c}\text { Profile } \\
\text { of the } \\
\text { retail } \\
\text { outlets }\end{array}$} & \multirow[b]{2}{*}{ Particulars } & \multirow{2}{*}{$\frac{\text { Kollam }}{\text { 胥 }}$} & \multirow{2}{*}{ 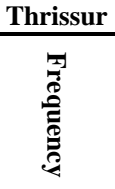 } & \multirow{2}{*}{ 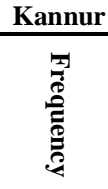 } & \multicolumn{2}{|c|}{ Total } \\
\hline & & & & & 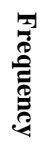 & 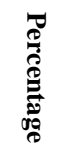 \\
\hline \multirow{6}{*}{ Sample } & $\begin{array}{l}\text { Municipal } \\
\text { Corporation }\end{array}$ & 6 & 6 & 6 & 18 & 37.5 \\
\hline & $\begin{array}{l}\text { Municipality } \\
1\end{array}$ & 3 & 3 & 3 & 9 & 18.75 \\
\hline & $\begin{array}{l}\text { Municipality } \\
2\end{array}$ & 3 & 3 & 3 & 9 & 18.75 \\
\hline & Panchayat 1 & 2 & 2 & 2 & 9 & 12.5 \\
\hline & Panchayat 2 & 2 & 2 & 2 & 9 & 12.5 \\
\hline & Total & 16 & 16 & 16 & 48 & 100 \\
\hline
\end{tabular}

\begin{tabular}{|c|c|c|c|c|c|c|}
\hline \multirow[b]{2}{*}{$\begin{array}{l}\text { Profile of the } \\
\text { retail outlets }\end{array}$} & \multirow[b]{2}{*}{$\begin{array}{c}\text { Particula } \\
\text { rs }\end{array}$} & \multirow{2}{*}{$\begin{array}{c}\begin{array}{c}\text { Kolla } \\
\text { m }\end{array} \\
\\
0 \\
\frac{8}{0} \\
\frac{0}{2}\end{array}$} & \multirow{2}{*}{$\begin{array}{c}\text { Thrissu } \\
\text { r } \\
\\
\end{array}$} & \multirow{2}{*}{$\begin{array}{c}\text { Kannu } \\
\mathbf{r} \\
\\
\frac{7}{8} \\
\frac{8}{0} \\
\frac{9}{2}\end{array}$} & \multicolumn{2}{|c|}{ Total } \\
\hline & & & & & 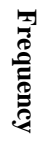 & 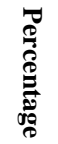 \\
\hline \multirow{6}{*}{$\begin{array}{c}\text { Type of } \\
\text { retail outlet }\end{array}$} & $\begin{array}{l}\text { Departme } \\
\text { nt Store }\end{array}$ & 0 & 0 & 4 & 4 & 8.33 \\
\hline & $\begin{array}{l}\text { Super } \\
\text { market }\end{array}$ & 12 & 9 & 5 & 26 & $\begin{array}{r}54.1 \\
7\end{array}$ \\
\hline & $\begin{array}{l}\text { Hyper } \\
\text { market }\end{array}$ & 4 & 2 & 0 & 6 & 12.5 \\
\hline & $\begin{array}{l}\text { Specialty } \\
\text { Store }\end{array}$ & 0 & 5 & 0 & 5 & $\begin{array}{r}10.4 \\
2\end{array}$ \\
\hline & Any Other & 0 & 0 & 7 & 7 & $\begin{array}{r}14.5 \\
8\end{array}$ \\
\hline & Total & 16 & 16 & 16 & 48 & 100 \\
\hline \multirow{7}{*}{$\begin{array}{c}\text { The total No. } \\
\text { of Staff }\end{array}$} & 1 to 10 & 8 & 6 & 8 & 22 & $\begin{array}{r}45.8 \\
3\end{array}$ \\
\hline & 11 to 20 & 6 & 7 & 3 & 16 & $\begin{array}{r}33.3 \\
3\end{array}$ \\
\hline & 21 to 30 & 2 & 2 & 2 & 6 & 12.5 \\
\hline & 31 to 40 & 0 & 0 & 1 & 1 & 2.08 \\
\hline & 41 to 50 & 0 & 1 & 2 & 3 & 6.25 \\
\hline & $>51$ & 0 & 0 & 0 & 0 & $\mathbf{0}$ \\
\hline & Total & 16 & 16 & 16 & 48 & 100 \\
\hline \multirow{4}{*}{$\begin{array}{l}\text { Total No. of } \\
\text { Staff } \\
\text { (Professional } \\
\text { s) }\end{array}$} & 1 to 10 & 10 & 16 & 15 & 41 & $\begin{array}{r}85.4 \\
2\end{array}$ \\
\hline & 11 to 20 & 6 & 0 & 1 & 7 & $\begin{array}{r}14.5 \\
8\end{array}$ \\
\hline & $>21$ & 0 & 0 & 0 & 0 & $\mathbf{0}$ \\
\hline & Total & 16 & 16 & 16 & 48 & 100 \\
\hline \multirow{7}{*}{$\begin{array}{c}\text { Total No. of } \\
\text { Staff (Non } \\
\text { Professionals } \\
\text { ) }\end{array}$} & 1 to 10 & 8 & 9 & 9 & 26 & $\begin{array}{r}54.1 \\
7\end{array}$ \\
\hline & 11 to 20 & 8 & 6 & 4 & 18 & 37.5 \\
\hline & 21 to 30 & 0 & 0 & 0 & 0 & $\mathbf{0}$ \\
\hline & 31 to 40 & 0 & 0 & 2 & 2 & 4.17 \\
\hline & 41 to 50 & 0 & 1 & 1 & 2 & 4.17 \\
\hline & $>50$ & 0 & 0 & 0 & 0 & $\mathbf{0}$ \\
\hline & Total & 16 & 16 & 16 & 48 & 100 \\
\hline
\end{tabular}

Further, Table No. 1 presents the different types of retail outlets from where the data was collected. It can be seen that $54.17 \%$ (26 numbers) of the retailers are supermarkets. There were 6 hyper markets $(12.5 \%), 5$ specialty stores $(10.42 \%)$ and 4 department stores $(8.33 \%)$.and $14.58 \%$ (7 numbers) of the outlets who responded that they did not belong with a specific category. 
The percentage of staff employed by the outlets shows that majority of the outlets i.e. $45.83 \%$ (220 numbers) are employing just 1 to 10 people. 16 outlets $(33.33 \%)$ are having less than 11 to 20 people, 6 retailers $(12.5 \%)$ claimed to have 21 to 30 staff members and 3 outlets $(3.25 \%)$ have 41 to 50 employees. 1 outlet $(2.08 \%)$ is having 31 to 40 employees. None of the outlets have more than 50 people as employees.

A separate analysis has been done regarding the number of professionals and the number of nonprofessionals. The percentage analysis of the number of professional staff working in the outlets shows that $85.42 \%$ of the retailers (41 numbers) have less than 10 professionals employed in their outlet. 7 outlets $(14.58 \%)$ have 11 to 20 professionals. None of the outlets have more than 20 people who are professionals among their staff.

Table No. 1 also presents the number and percentage of nonprofessional employees working in the retail outlets. $54.17 \%$ (26 numbers) of the outlets have less than 10 nonprofessionals and $37.5 \%$ (18 numbers) of the retail outlets have between 11 and 20 employees who are nonprofessionals. $4.17 \%$ ( 2 numbers) of the outlets have 31 to 40 nonprofessional employees and another $4.17 \%$ (2 numbers) have 41 to 50 people. As described before none of the outlets have more than 50 employees.

\section{DATA ANALYSIS \& RESULTS}

To understand the precautions taken by a retail outlet with respect to employee training in handling an emergency situation.

\section{Hypothesis}

$\mathrm{H}^{\circ}$ : The employees are not aware of any plan/process that has to be followed in case an emergency situation arise.

\section{Analysis}

1. Mann Whitney U Test (Employees and training programs on emergency preparedness)

Mann-Whitney $U$ test is a non-parametric test used instead of independent sample $\mathrm{T}$ test to compare two sample means that come from the same population, to know whether they are equal or not. In this research MannWhitney $U$ test is used to access whether the employees are trained regularly on the emergency management processes and practices.

\begin{tabular}{|l|l|r|r|r|r|r|}
\hline \multicolumn{7}{|c|}{ Table No. 2: Employees and training programs on emergency } \\
preparedness
\end{tabular}

(Significance level: 0.05)
According to the Table No. 3 in Kollam the professionals who attended the training programs $(\mathrm{M}=13.5)$ were more than those who had not attended ( $M=7.79)$. The $\mathrm{p}$-value for professionals who did training $(\mathrm{p}=0.059)$ was more than the level of significance and so the null hypothesis was accepted. The non-professionals who got trained $(\mathrm{M}-12.5)$ was also more than those who were not trained $(M-7.93)$. Here again the $\mathrm{p}$-value was $(\mathrm{p}=0.143)$ more than the significance level and so the null hypothesis was accepted.

For the district of Thrissur the professionals who attended the training programs $(\mathrm{M}=8.5)$ were equal to those who had not attended $(M=8.5)$. The p-value for professionals who did training $(\mathrm{p}=1.000)$ was more than the level of significance and so the null hypothesis was accepted. The non-professionals who got trained $(\mathrm{M}-12.5)$ was more than those who were not trained $(M-7.93)$. Here again the $p$ value was $(p=0.148)$ more than the significance level and so the null hypothesis was accepted.

In Kannur the professionals who attended the training programs $(M=8.000)$ were less than those who had not attended $(\mathrm{M}=8.53)$. The $\mathrm{p}$-value for professionals who did training $(p=0.796)$ was more than the level of significance and so the null hypothesis was accepted. The nonprofessionals who got trained $(\mathrm{M}-11.5)$ were more than those who were not trained $(\mathrm{M}-8.3)$. Here again the $\mathrm{p}$ value was $(p=0.469)$ more than the significance level and so the null hypothesis was accepted.

\section{INTERPRETATION}

1. Majority of the retail outlets that are functioning in the districts of Kollam, Thrissur and Kannur are super markets followed by specialty stores and hyper markets.

2. Most of the outlets have less than twenty people as their total staff.

3. The total number of professionals working in retail outlets is below ten in most of the places.

4. None of the outlets have more than twenty professionals.

5. The total number of non-professional also stays within twenty with just four outlets having employees between thirty and fifty

6. In Kollam the mean of the professional employees who had attended any kind of training programme regarding emergency management is more than those who have not attended. Same is the case of non-professionals also. But it is not sufficient enough to reject the null hypothesis

7. In Thrissur the mean of professional who got trained and who did not get trained are equal.

The non-professionals who got trained in emergency management systems were more than those who did not get any training. But here again the p-value was more than 0.05 and the null hypothesis was accepted. 
8. In the case of Kannur the professional who did not get any training were more than those who got trained. But in the case of non-professionals, those who got training was more than those who did not. But the p-value was more than the significant level.

9. The retail employees of the districts of Kollam, Thrissur and Kannur have not received any training regarding how to face an emergency situation while at work.

10. The mean of the employees who received any kind of training goes on decreasing as the study moves towards the north.

11. The district of Kollam has more trained employees than Thrissur and Kannur.

\section{CONCLUSION}

The emergency management practices available in the retail outlets are far too insufficient to mitigate and manage an unexpected risky situation. Disaster preparedness and mitigation goes a long way to help reduce the after effects of an emergency situation. This is possible only through systematic training programs along with providing the necessary equipment. The retail industry of the state is bound to stay and grow. Kerala has to go a long way towards making emergency management practices an essential component in the employee training procedure as part of customer service in retail outlets.

\section{REFERENCES}

1. Dangi, H K. and Dewan, S. (2016), "Business Research Methods", Cengage Learning India Pvt. Ltd. New Delhi.

2. Kothari, C. R. and Garg, G. (2016), "Research Methodology-Methods and Techniques", New Age Techno Press. New Delhi.

3. Argyrous, G. (2011), "Statistics for research-A guide to SPSS", Sage Publications, New Delhi.

4. Varley, R. and Rafiq. M. (2005), "Principles of Retail Management”, Palgrave Macmillan, New York.

5. UNISDR

Reporthttp://www.unisdr.org/we/inform/terminologyAcc essed 02 Nov 2014.

6. National Policy on Disaster Management NDMA 2009

7. MHA Disaster Management in India Ministry of Home Affairs Report 2011

8. Kerala State Disaster Management Plan 2006

9. Wikipedia https://en.wikipedia.org/wiki/2015_South_Indian_floods Accessed 5 Feb 2018

10. sdma.kerala.gov.in/(Kerala State Disaster management authority)

11. www.censusindia.gov.in/2011census/PCA/PCA_Highlig hts/.../India/Chapter-1.pdf

12. Birkmann John (2006), "measuring vulnerability to natural hazards", edited by TERI Press, New Delhi, India, pp. 34-95.

13. CrisKochukalam., Kinslin D. (2017) "A Study Among Decorative Paint Customers on Factors Influencing Preference of Decorative Paint Brands" International Journal of Applied Business and Economic Research Volume15 No.6 ISSN: 0972-7302

14. CrisKochukalam., Kinslin D. (2017) "Problems and Challenges of Decorative Paint Customers in Paint Preference: A Study Among Decorative Paint Customers of Kerala" International Journal of Applied Business and Economic Research Volume15 No.6 ISSN: 0972-7302
15. Edmund Christopher.S (2015), "Employee Training and Development Practices in Air India - A Descriptive Glance with Reference to Chennai" International Journal of Applied Engineering Research, Research India Publications, ISSN 0973-4562, Vol.10, No.45, pp 3200532008.

16. Edmund Christopher.S (2014), "Performance of Air India with Special Reference to Passenger Fluctuations- A Focus" Indian Stream Research Journal, Impact Factor. 2.1506(UIF), ISSN: 2230-7850, Vol. 4, Issue - 10, pp. 01-06

17. 'Survey and Analysis of buildings in the State of Kerala falling under the purview of Energy Conservation Act 2001', Kerala State Productivity Council. November 2016.

18. UNISDR (2005), "Building the Resilience of Nations and Communities to Disasters", Hyogo Framework for Action, World Conference on Disaster Reduction, Kobe, Japan.

19. WHO (2002), "Gender and Health of Disasters", World Health Organization, Department of Gender and Women's Health, Geneva, 240.

20. https://www.tripadvisor.in/ShowUserReviews-g297633d4021055-r434308429-LuLu_Mall-

Kochi_Cochin_Ernakulam_District_Kerala.html\#

21. Edmund Christopher.S (2015) "An analytical Study on Service Quality of Air India with Special Reference to Southern Region", International Journal of Applied Engineering Research, Research India Publications, ISSN 0973-4562, Vol.10, No.45, pp 32021-32024.

22. Dhanya.J.S., Kinslin D. (2017) "A Study on Impact of Work Life Balance on Retention of Women Teachers in Management Colleges in Kerala" International Journal of Applied Business and Economic Research Volume15 No.4 ISSN: 0972-7302

23. Dhanya.J.S., Kinslin D. (2017) “A Study on Work Life Balance of Women Employeees at ULCCS Ltd., Kozhikode" International Journal of Applied Business and Economic Research Volume15 No.4 ISSN: 09727302

24. Dhanya.J.S., Kinslin D. (2017) "Clair Model for Better Work Life Balance and Empowerment of Women Faculty in Professional Colleges of Kerala" International Journal of Applied Business and Economic Research Volume15 No.4 ISSN: 0972-7302

25. CrisKochukalam., Kinslin D. (2017) "A Study on the Factors for Intermediary Dependence Among Decorative Paint Customers Exploring the impact significance " International Journal of Applied Business and Economic Research Volume15 No.6 ISSN: 0972-7302

26. CrisKochukalam., Kinslin D. (2017) "A study Explaining Branding Brand Experience Among Decorative Paint customers" International Journal of Applied Business and Economic Research Volume15 No.6 ISSN: 0972-7302

27. Shaji, Y., Kinslin, D., Janardhanan, K.A. (2015). "Employee Retention Practices for Leaders - A Study in Information Technology Organization", International Journal of Applied Engineering Research, VOLUME NO. 10 (2015), ISSUE NO. 45. ISSN 0973-4562. 